\title{
ANALISIS KEGAGALAN PADA WHEEL HEAD SPOOL
}

\section{FAILURE ANALYSIS ON THE WHEEL HEAD SPOOL}

\author{
Kosasih, Kuntari Adi Suhardjo \\ Balai Besar Bahan dan Barang Teknik, Jl. Sangkuriang No.14 Bandung 40135 \\ Email: logam@b4t.go.id
}

Diterima: 18 April 2013

Direvisi: 14 Mei 2013

Disetujui: 10 Juni 2013

\begin{abstract}
ABSTRAK
Kegagalan dari suatu komponen dapat disebabkan oleh berbagai faktor, mulai dari kesalahan pemilihan material sampai dengan kesalahan operator dalam servisnya. Kasus yang disajikan disini adalah analisis terhadap Wheel Head Spool yang mengalami pecah disebabkan oleh korosi erosi dan aliran turbulensi gas pada daerah yang bersifat anodik akibat adanya logam yang dissimilar (korosi galvanis). Disamping itu pada permukaan dalam hasil pengelasan (daerah akar las) terbentuk takikan dimana arus aliran gas akan menabrak daerah tersebut, sehingga terjadi arus turbulensi yang sifatnya menahan/stagnasi. Beberapa pendekatan yang dilakukan untuk mengetahui penyebabnya dilakukan analisis kegagalan melalui pemeriksaan yaitu: (1) visual dan dimensi, (2) makroskopis dan mikroskopis, (3) komposisi kimia bahan, (4) kuat tarik dan kekerasan, (5) Scanning Electron Microscope (SEM) dan Energy Dispersed Spectrometry (EDS). Hasil analisis membuktikan bahwa kegagalan pada Wheel Head Spool karena adanya korosi pada sambungan las flange, reducer dan pipa penyalur. Sambungan pengelasan logam yang berbeda menyebabkan kekerasannya berbeda sehingga terjadi galvanik karena adanya Heat-Affected Zone (HAZ) bersifat anodik yang mempunyai kekerasan lebih tinggi dan lainnya bersifat anodik. Untuk mencegah kegagalan di masa yang akan datang maka direkomendasikan sebagai berikut: (1) hindari terjadinya pengelasan dengan material yang berbeda, (2) jika akan dilakukan dengan pengelasan yang berbeda, maka pengelasan metode buttering harus dilakukan, (3) hindari daerah penyempitan pada daerah flange dan line pipe.
\end{abstract}

Kata kunci: analisis kegagalan, wheel head spool, korosi

\section{ABSTRACT}

Failure of a part can be caused by various factors, error ranging from material selection to errors with errors in its service provider. Case presented here is an analysis of the Wheel Head Spool rupture caused by erosion and corrosion of gas flow turbulence on the anodic area is due to the dissimilar metals (galvanic corrosion). Besides, on the surface of the weld (weld root area) formed a notch where the gas stream flows will crash in the area, resulting in turbulence flow properties hold/ stagnation. Several approaches were made to determine the cause of failure analysis is done using several testing such as: (1) visual and dimensional, (2) macroscopic and microscopic, (3) the chemical composition of materials, (4) tensile and hardness, (5) Scanning Electron Microscope (SEM) and Energy Dispersed Spectrometry (EDS). Analysis results prove that the failure to Wheel Head Spool due to corrosion of the weld flange, reducer and conduit. Welding connection of different metals cause different hardness which causing galvanic because the Heat-Affected Zone (HAZ) is anodic which has a higher hardness and others are anodic. To prevent failures in the future it is recommended as follows: (1) avoid the occurrence of welding with different materials, (2) if it will be done with different welding, the welding must be done by buttering method, (3) avoiding the narrowing in the region flange and line pipe.

Keywords: failure analysis, wheel head spool, corrosion

\section{PENDAHULUAN}

Alasan utama untuk melakukan analisis kegagalan adalah untuk menentukan dan menjelaskan faktor-faktor penyebab kegagalan dari suatu komponen. Berdasarkan pandangan keteknikan, hasil analisis kegagalan merupakan umpan balik yang sangat berharga bagi masalah masalah desain baik yang menyangkut struktur, fabrikasi, dan desain bahan.

Kegagalan dari suatu komponen adalah ketidakmampuan komponen tersebut berfungsi sebagaimana mestinya yang dapat dimulai dari terbentuknya permukaan baru (retakan, patahan), karatan, maupun gabungan diantara keduanya ataupun keausan yang tidak terencana. Kegagalan 
dapat juga disebabkan oleh distorsi ukuran, distorsi bentuk atau perubahan volume, tetapi kegagalan jenis ini tidak akan dibahas. Analisis kegagalan dilakukan secara menyeluruh, mulai dari evaluasi perencanaan sampai dengan evaluasi pemakaian dari suatu komponen.

Faktor-faktor utama yang berhubungan dengan analisis kegagalan dari suatu komponen adalah sebagai berikut: (1) kesalahan perencanaan, (2) kesalahan pemilihan bahan, (3) fabrikasi yang tidak mengikuti prosedur, (4) kesalahan penggabungan dan (5) kesalahan dalam operasi.

Kegagalan dapat bersumber pada salah satu faktor tersebut di atas atau dapat pula merupakan gabungan dari dua faktor atau lebih. Faktor penyebab kegagalan pada umumnya sangat sulit untuk dipastikan kecuali bila penelitian yang secara insentif dilakukan.

Kegiatan analisis kegagalan selalu diawali dengan mengumpulkan data lapangan atau informasi yang selengkap mungkin, kemudian penentuan masalah, pembuatan hipotesis, kesimpulan dan saran pencegahannya.

\section{Analisis Kegagalan}

Berdasarkan teori analisis kegagalan (failure analysis), adalah kegiatan atau usaha untuk menyelidiki sebab-sebab kegagalan suatu komponen. Semua indikasi dipelajari dan diteliti untuk mendapatkan keputusan komponen layak diperbaiki atau tidak. Modus kegagalan dapat berupa keausan atau takikan komponen mengalami patah atau pecah [1].

\section{Korosi Secara Umum}

Korosi dapat didefinisikan sebagai proses penurunan atau kerusakan suatu material logam yang ditimbulkan oleh reaksi logam dengan lingkungan sekitarnya [2,3]. Lingkungan yang dapat menyebabkan timbulnya kerusakan logam dalam menjalankan fungsinya, seperti udara dan uap air, larutan berair, suhu tinggi, biologi dan mekanis.

Ketahanan korosi suatu material dapat ditinjau dari berbagai faktor, yaitu: (1) Metalurgi, (2) Elektrokimia, (3) Fisik dan kimia, (4) Termodinamik, seperti ditunjukkan pada Gambar 1.

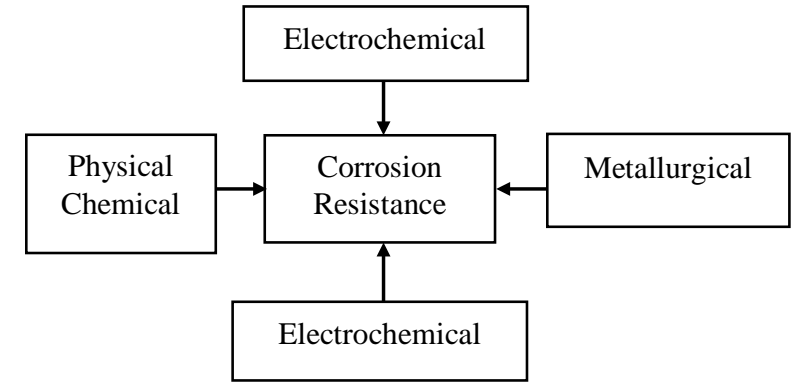

Gambar 1. Faktor-Faktor yang Mempengaruhi Ketahanan Korosi Logam [4]

Faktor elektrokimia termasuk proses korosi basah dan terjadi karena adanya perbedaan potensial antara dua permukaan logam yang mengakibatkan permukaan berpotensial lebih rendah teroksidasi, dengan demikian terjadilah korosi. Untuk mendukung terjadinya korosi basah ada 3 (tiga) faktor yang mempengaruhinya, yaitu: (1) Adanya konduktansi listrik pada anoda dan katoda, (2) Adanya perbedaan potensial antara dua bagian permukaan logam yakni anoda, (3) Hadirnya elektrolit.

Pada prinsipnya proses korosi akan terjadi bila terdapat reaksi antara anodik dengan katodik, yang ditunjukkan dalam Gambar 2. Kombinasi antara anoda, katoda dan elektrolit disebut sebagai sistem sel korosi. Peristiwa reaksi korosi logam besi didalam medium air adalah sebagai berikut:

$\mathrm{Fe}+\mathrm{H}_{2} \mathrm{O} \longrightarrow \mathrm{Fe}(\mathrm{OH})_{2}+\mathrm{H}_{2}$

Persamaan reaksi (1) merupakan penjumlahan dari dua reaksi berikut :

$\mathrm{Fe} \longrightarrow \mathrm{Fe}^{2+}+2 \mathrm{e}-$

$1 / 2 \mathrm{O}_{2}+\mathrm{H}_{2} \mathrm{O}+2 \mathrm{e}^{-} \longrightarrow 2(\mathrm{OH})^{-}$

Reaksi yang dinyatakan oleh persamaan (2) dan (3) berlangsung di permukaan logam. Sebagai anoda dan mempunyai potensial yang lebih rendah, sedangkan bagian permukaan dimana reduksi berlangsung disebut sebagai katoda. Sedangkan reaksi korosi pada lingkungan yang agresif seperti garam klorida dituliskan sebagai berikut: 


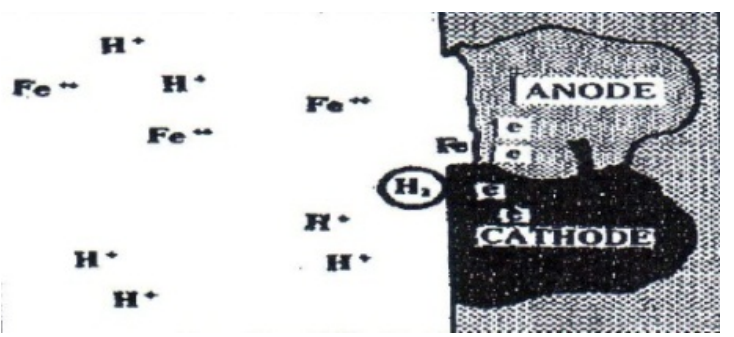

Gambar 2. Reaksi Anodik dan Katodik pada Permukaan Logam [5]

Anoda $: \mathrm{Fe} \longrightarrow \mathrm{Fe}^{2+}+2 \mathrm{e}$

Katoda : $1 / 2 \mathrm{O}_{2}+\mathrm{H}_{2} \mathrm{O}+2 \mathrm{e}^{-} \longrightarrow 2(\mathrm{OH})^{-}$

Adanya ion $\mathrm{Cl}^{-}$, maka reaksi total elektro kimia menjadi :

$\mathrm{Fe}+2 \mathrm{H}_{2} \mathrm{O}+2 \mathrm{Cl}^{-} \longrightarrow \mathrm{Fe}(\mathrm{OH})_{2}+\mathrm{HCl}$

\section{BAHAN DAN METODE}

\section{Bahan Analisis}

Wheel Head Spool yang mengalami pecah, adapun rincian data teknis identitas barang Wheel Head Spool A*Cs NB\#5 adalah sebagai berikut:

- Jenis material:

- RTJ Flange : Stainless Steel

- Reducer : Carbon Stell (SA-274-WPB)

- Pipa : SA 106 B

- Suhu operasi : $150^{\circ} \mathrm{F}$

- Tekanan operasi : 800 psig

- Untuk melayani : gas (Tabel 1)

Terjadinya bocor Wheel Head Spool kemungkinan disebabkan oleh korosi erosi dan aliran turbulensi gas pada daerah yang bersifat anodik akibat adanya logam yang dissimilar (korosi galvanis). Disamping itu pada permukaan dalam hasil pengelasan (daerah akar las) terbentuk adanya takikan dimana arus aliran gas akan menabrak daerah tersebut, sehingga terjadi arus turbulensi yang sifatnya menahan/ stagnasi.

Tabel 1. Komposisi Gas Alam yang Melewati Wheel Head Spool

\begin{tabular}{clc}
\hline No. & Komponen Gas Alam & \% Mol \\
\hline 1. & Oksigen & 0,00 \\
2. & Nitrogen & 1,88 \\
3. & Karbon dioksida & 2,33 \\
4. & Metan & 73,42 \\
5. & Etan & 8,9 \\
6. & Propan & 8,80 \\
7. & Iso-Butan & 1,44 \\
8. & n-Butan & 1,83 \\
9. & Iso-Pentan & 0,54 \\
10. & n-Pentan & 0,41 \\
11. & Heksan $\left(\mathrm{C}_{6} \mathrm{H}_{13}{ }^{+}\right)$ & 0,41 \\
\hline
\end{tabular}

Skema penelitian untuk mencari penyebab kegagalan yang terjadi pada Wheel Head Spool dilakukan dengan menggunakan metode analisis kegagalan yang ditunjukkan pada Gambar 3.

Metode penelitian dilakukan dengan menggunakan peralatan pengujian sebagai berikut: (a) pemeriksaan visual dan dimensi, (b) pemeriksaan makroskopis dan mikroskopis, (c) pengujian komposisi kimia, (d) pengujian kekerasan, (e) pengujian SEM dan EDS. Hasil pemeriksaan dan pengujian akan mendukung analisis dari kegagalan tersebut.

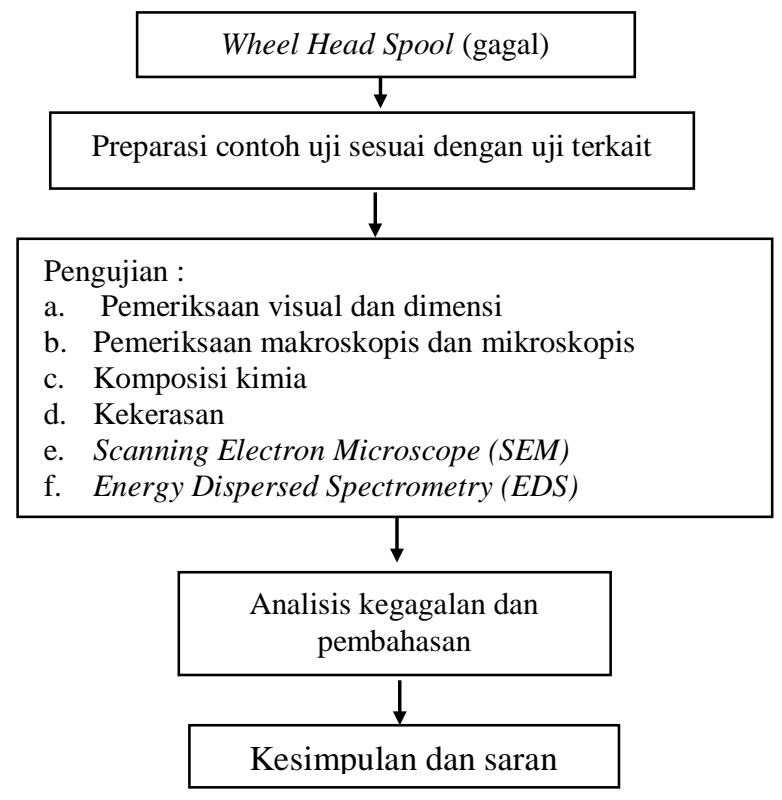

Gambar 3. Metode Percobaan 


\section{Metode Percobaan}

Preparasi contoh uji sebagai bahan analisis dilakukan terhadap Wheel Head Spool A*Cs NB\#5 yang gagal sesuai dengan uji terkait antara lain: pemeriksaan visual dan dimensi, pemeriksaan makroskopis dan mikroskopis, komposisi kimia, kekerasan, SEM, dan EDS, kemudian dilakukan analisis kegagalan, pembahasan, kesimpulan dan saran.

\section{HASIL DAN PEMBAHASAN}

\section{Pemeriksaan Visual dan Dimensi}

Visualisasi dari pecahnya Flange dan Reducer itu terletak di daerah sambungan las yang diduga pada daerah HAZ. Adanya pengelasan maka terbentuk root hasil pengelasan yang merupakan takikan (notch) pada permukaan bagian dalam. Takikan pada permukaan bagian dalam akan menyebabkan terjadinya arus turbulensi, disamping itu pada daerah las, khususnya HAZ memiliki kekerasan yang tinggi (170 HV s/d $194 \mathrm{HV}$ ) yang artinya daerah HAZ tersebut bersifat anodik. Adanya aliran gas di dalam dengan kecepatan yang tinggi serta bersuhu dengan tekanan yang tinggi, maka daerah HAZ tersebut akan mengalami pengikisan.

Dari hasil pengamatan visual pada bagian luar benda uji terlihat adanya lubang dekat daerah pengelasan, antara flange dengan reducer seperti diperlihatkan pada Gambar 4. Pada bagian dalam terlihat adanya pengikisan oleh aliran media pada daerah pengelasan yang mempunyai takikan (notch) yang cukup signifikan dan mengakibatkan terjadinya penipisan seperti ditunjukkan pada Gambar 5. Pada bagian dalam terlihat adanya pengikisan oleh aliran media pada daerah pengelasan yang mempunyai takikan (notch) yang cukup signifikan dan mengakibatkan terjadinya penipisan seperti terlihat pada Gambar 6 dan 7. Secara visual terjadinya penipisan kemungkinan adanya pengikisan dari aliran fluida yang bergerak secara turbulensi dan stagnasi pada daerah tersebut. Disamping itu terlihat adanya material yang berbeda antara flange, reducer dan pipa. Kemungkinan perbedaan material flange dan reducer akan mengakibatkan terjadi korosi Galvanik. Selain itu pada daerah tersebut akan bersifat Anodik. Dengan kecepatan alir yang tinggi maka akan lebih mudah terjadi pengikisan [6]. Adanya pengikisan telah dibuktikan dengan pengukuran dimensi contoh dengan hasil sebagai berikut:
- Panjang flange dengan reducer $(\mathrm{mm})=210$

- Diameter luar flange (ØD) $(\mathrm{mm})=240$

- Diameter dalam flange (ID) $(\mathrm{mm})=74$

- Diameter luar pipa (ØD ) $(\mathrm{mm})=118$

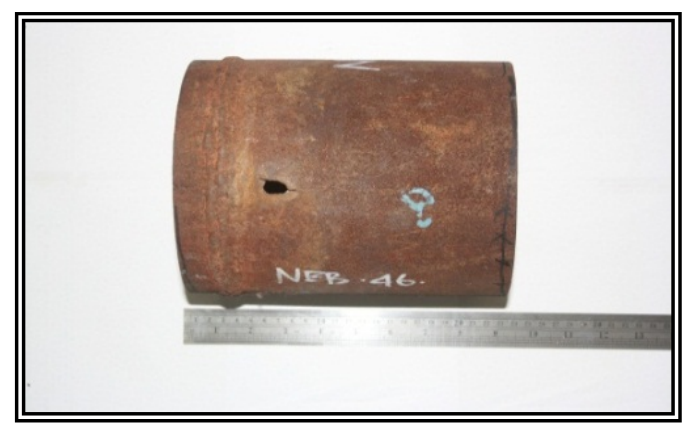

Gambar 4. Lokasi Visual Benda Uji

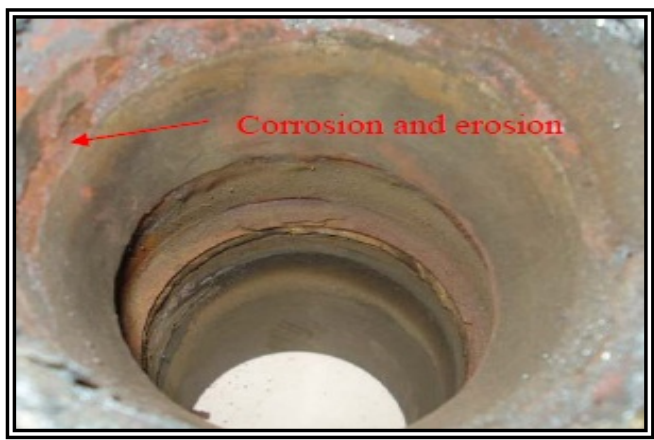

Gambar 5. Visual Daerah Bocor

\section{Uji Makroskopis dan Mikroskopis}

Hasil foto makroskopis terlihat pada Gambar 6 dan Gambar 7, menunjukkan adanya indikasi pengikisan yang disebabkan oleh media gas yang mempunyai sifat pengikisan yang signifikan, seperti karbon dioksida dan heksan $\left(\mathrm{C6}^{+}\right)$. Kedua zat kimia tersebut dapat melarutkan material yang keras dan getas. Disamping itu pada profil permukaan kondisinya tidak rata, bahkan terdapat takikan hasil pengelasan. Kedua penyebab tersebut di atas yang mengakibatkan terjadinya penipisan dan akhirnya mengalami kebocoran.

Selain itu komposisi kimia dari ke 3 jenis material yaitu flange, reducer dan pipa penyalur mempunyai jenis yang berbeda. Material flange termasuk Baja Tahan Karat $(11,89 \mathrm{Cr}-1,57 \mathrm{Ni})$, sedangkan reducer dan pipa penyalur terbuat dari baja karbon rendah. Penyambungan flange dengan reducer termasuk pengelasan material yang berbeda (dissimilar metal) yang akan menimbulkan risiko tinggi. Terbentuknya korosi galvanik, karena perbedaan potensial. Untuk pengelasan material yang berbeda perlu dilakukan proses pengelasan Buttering dengan tujuan untuk menghindar terjadinya korosi 
galvanik. Material flange bagian yang pecah mempunyai struktur Austenit (Tabel 6). Sedangkan, material reducer dan pipa penyalur pada bagian yang pecah dan retak memiliki Struktur Ferit-Perlit, sedangkan akibat adanya pengikisan maka akan terbentuk korosi sumuran yang dibantu unsur korosif seperti khlor $\left(\mathrm{Cl}^{-}\right)$dan sulfur $\left(\mathrm{S}^{-2}\right)$. Disamping itu pada profil permukaan kondisinya tidak rata, bahkan terdapat takikan hasil pengelasan. Kedua penyebab tersebut di atas yang mengakibatkan terjadinya penipisan dan akhirnya mengalami kebocoran [7].

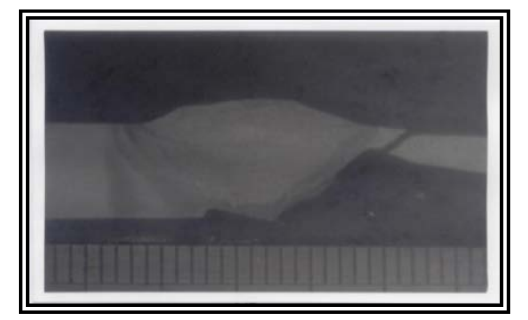

Gambar 6. Foto Makro Daerah Las

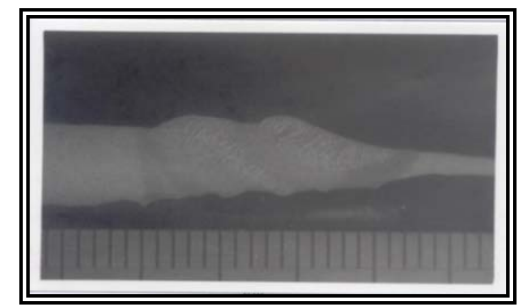

Gambar 7. Foto Makro Antara Reducer dan Pipa Antara Flange dan Reducer

\section{Uji Kekerasan}

Pengujian kekerasan dilakukan dengan metoda Vickers Test pada 3 (tiga) daerah sebagai berikut:

1. Daerah satu (1) Sambungan flange to reducer dapat dilihat pada Gambar 8. Pada Tabel 2 ditunjukkan hasil uji kekerasan pada sambungan flange dan reducer, menunjukkan nilai kekerasan yang mencolok, terutama pada HAZ, jadi jelas pada daerah HAZ akan bersifat anodik yang efeknya terhadap serangan korosi erosi. Mengingat adanya aliran gas arahnya dari reducer, maka terjadi aliran turbulensi di sekitar takikan (nocht) daerah reducer. Maka terjadilah penipisan yang selanjutnya akan berkembang menjadi lubang dan terjadilah kebocoran.

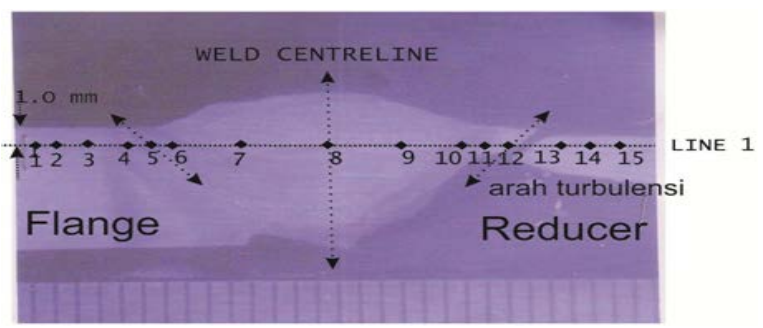

Gambar 8. Lokasi Uji Keras Flange ke Reducer

Tabel 2. Hasil Pengujian Kekerasan dengan Metoda Vickers (HV 1 kgf/mm²)

\begin{tabular}{ccc}
\hline Uji ke & Posisi & Kekerasan/HV 1/15 $\left(\mathrm{kgf} / \mathrm{mm}^{2}\right)$ \\
\hline 1 & & 169 \\
\hline 2 & Base metal (logam induk) & 157 \\
\hline 3 & & 240 \\
\hline 4 & & 325 \\
\hline 5 & HAZ & 367 \\
\hline 6 & & 371 \\
\hline 7 & & 159 \\
\hline 8 & Weld & 148 \\
\hline 9 & & 169 \\
\hline 10 & & 170 \\
\hline 11 & HAZ & 158 \\
\hline 12 & + & 163 \\
\hline 13 & BM & 182 \\
\hline 14 & & 181 \\
\hline 15 & & 178 \\
\hline
\end{tabular}




\section{Zona Perpipaan/Line Pipe Zone (SA 106 B)}

Dari Tabel 3 terlihat bahwa hasil uji kekerasan pada pipa (line pipe) nilainya bervariasi. Pada daerah ujung Crack (retak) mempunyai nilai kekerasan yang tinggi. Jadi kemungkinan awal retak mempunyai nilai kekerasan yang lebih tinggi. Dengan demikian pada daerah yang mempunyai nilai kekerasan tinggi akan rentan terhadap serangan korosi, karena di daerah tersebut bersifat anodik [8].

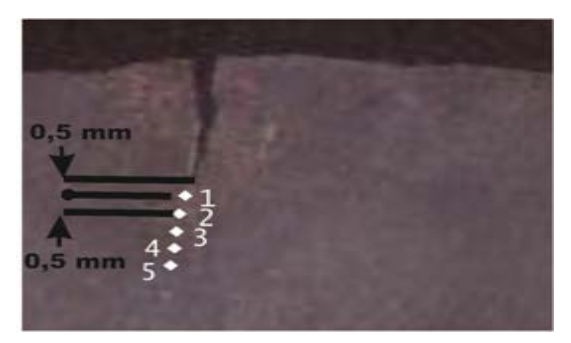

Gambar 9. Lokasi Uji Keras Ujung Pipa Pecah

Tabel 3. Hasil Pengujian Kekerasan Metoda Vickers Test HV $\left(\mathrm{kgf} / \mathrm{mm}^{2}\right)$

\begin{tabular}{clc}
\hline Uji ke & \multicolumn{1}{c}{ Posisi } & $\begin{array}{c}\text { Kekerasan } \\
\text { (kgf/mm }\end{array}$ \\
\hline 1 & Ujung Crack & 240 \\
\hline 2 & Ujung Crack & 211 \\
\hline 3 & Dekat Ujung Crack & 213 \\
\hline 4 & Jauh dari Ujung Crack & 219 \\
\hline 5 & Jauh dari Ujung Crack & 215 \\
\hline
\end{tabular}

\section{Zona flange - reducer - pipa}

Dari ketiga jenis komoditi/barang, yaitu: flange - reducer - pipa menunjukkan adanya pengikisan di permukaan bagian dalam. Bagian dalam yang mudah terkikis oleh media gas yang mengalir adalah barang yang materialnya mempunyai nilai kekerasan yang lebih tinggi dibanding dengan lainnya. Hal ini terlihat pada Gambar 10. Dengan adanya korosi erosi yang disebabkan oleh aliran gas yang tinggi akan mengakibatkan terjadinya pengikisan yang signifikan, mengingat bahwa gas memiliki kandungan unsur hidrokarbon, karbon dioksida dan heksan yang bersifat sebagai pelarut yang mengakibatkan pengikisan [9] .

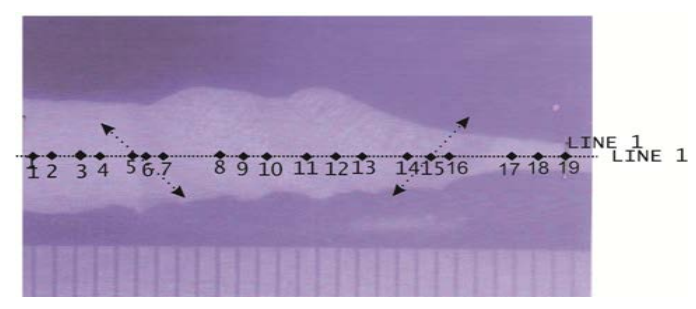

Gambar 10. Lokasi Uji Keras Flange-Reducer-Pipa

Tabel 4. Hasil Uji Kekerasan dengan Metoda Vickers

\begin{tabular}{ccc}
\hline Uji ke & Posisi & Kekerasan $\left.\mathbf{( k g f} / \mathbf{m m}^{\mathbf{2}}\right)$ \\
\hline 1 & & 142 \\
\hline 2 & Base metal (logam induk) & 138 \\
\hline 3 & & 144 \\
\hline 4 & HAZ & 148 \\
\hline 5 & & 146 \\
\hline 6 & & 155 \\
\hline 7 & Weld & 170 \\
\hline 8 & & 167 \\
\hline 9 & & 163 \\
\hline 10 & Weld & 179 \\
\hline 11 & & 179 \\
\hline 12 & & 196 \\
\hline 13 & HAZ & 197 \\
\hline 14 & & 194 \\
\hline 15 & & 184 \\
\hline 16 & Base metal & 181 \\
\hline 17 & & 182 \\
\hline 18 & & 179 \\
\hline 19 & & 180 \\
\hline
\end{tabular}




\section{Komposisi Kimia}

Hasil uji komposisi kimia benda uji dilakukan dengan metode Spektro emisi terhadap barang/komoditi flange - reducer - pipa yang dapat dilihat pada Tabel 5. Untuk komoditi flange, materialnya memiliki komposisi unsur Cr-Ni yang termasuk material baja tahan karat austenitik, sedangkan material reducer dan pipa termasuk baja karbon rendah, yang apabila dilakukan pengelasan tidak terjadi masalah. Akan tetapi apabila dilakukan pengelasan dengan jenis material yang berbeda akan memiliki resiko tinggi. Agar tidak berisiko tinggi maka spesifikasi pengelasan yang benar harus diikuti. Pengelasan dengan jenis material yang berbeda akan memudahkan terbentuknya korosi galvanik, dan bila ada aliran gas yang memiliki debit, suhu dan tekanan yang tinggi akan mengikis material bagian barang yang telah mengalami korosi galvanik tersebut. Peristiwa ini dikenal dengan istilah korosi erosi [7].
Tabel 5. Hasil Uji Komposisi Kimia

\begin{tabular}{cccc}
\hline Unsur (\%) & Flange & Reducer & Pipa \\
\hline $\mathrm{C}$ & 0,964 & 0,118 & 0,185 \\
\hline $\mathrm{Si}$ & 0,284 & 0,244 & 0,218 \\
\hline $\mathrm{Mn}$ & 0,226 & 0,542 & 0,552 \\
\hline $\mathrm{P}$ & 0,0090 & 0,0020 & 0,0092 \\
\hline $\mathrm{S}$ & 0,0026 & 0,0028 & 0,0011 \\
\hline $\mathrm{Cr}$ & 11,84 & - & - \\
\hline $\mathrm{Ni}$ & 1,57 & - & - \\
\hline $\mathrm{Mo}$ & 0,0109 & - & - \\
\hline
\end{tabular}

\section{Uji Mikrostruktur}

Pengujian struktur mikro dilakukan untuk mengetahui kondisi butiran akibat proses pengoperasian benda uji. Pengujian ini juga untuk mengetahui jenis material yang telah mengalami degradasi akibat pengaruh lingkungan sekitar tempat dioperasikannya benda uji. Penjelasan rinci tentang uji struktur mikro dapat dilihat pada Tabel 6 .

Tabel 6. Hasil Pemeriksaan Mikrostruktur

\begin{tabular}{|c|c|c|c|}
\hline No & Komoditi & Posisi & Hasil Pemeriksaan \\
\hline 1 & Flange & Daerah pecah & $\begin{array}{l}\text { Daerah pecah terletak pada alasan (HAZ), dengan } \\
\text { mikrostruktur austenit }(11,89 \mathrm{Cr}-1,57 \mathrm{Ni})\end{array}$ \\
\hline 2 & Reducer & $\begin{array}{l}\text { Daerah pecah permukaan } \\
\text { dalam }\end{array}$ & $\begin{array}{l}\text { Struktur ferit-perlit, terdapat korosi sumuran akibat } \\
\text { adanya arus turbulensi yang mengakibatkan korosi } \\
\text { erosi. Korosi makin parah didukung oleh pengaruh } \\
\text { unsur klor }\left(\mathrm{Cl}^{-}\right) \text {dan sulfur }\left(\mathrm{S}^{-2}\right)\end{array}$ \\
\hline 3 & Pipa & Daerah retak & $\begin{array}{l}\text { Struktur ferit-perlit dengan ukuran butir } 7-8 \text { ASTM. } \\
\text { Terdapat korosi sumuran sama seperti terjadi pada } \\
\text { reducer. Pada ujung retakan terdapat retakan } \\
\text { transanguler }\end{array}$ \\
\hline
\end{tabular}

Pengamatan terhadap material ketiga jenis barang/komoditi (yaitu: flange-reducer-pipa) menunjukkan hasil yang sama, yaitu adanya pengaruh aliran arus turbulensi dan stagnasi pada daerah yang bersifat anodik, sehingga terjadi korosi erosi, korosi sumuran yang didukung oleh adanya unsur kimia klor $\left(\mathrm{Cl}^{-}\right)$dan sulfur $\left(\mathrm{S}^{-2}\right)$ yang ada di lingkungan sekitar lokasi. Hal tersebut lama kelamaan akan menimbulkan lubang sehingga terjadi kebocoran [7].

\section{Pemeriksaan SEM dan EDS}

Pada pengujian dengan Scanning Electron Microscope (SEM) secara kualitatif menunjukkan adanya kerak (scale) yang rapat dan menyatu seperti terlihat pada Gambar 11 dan Gambar 12. Kerak tersebut akan mempermudah terjadinya penetrasi dari unsur korosif karena kerak bersifat porous. Kerak pada flange dan pipa kondisinya hampir sama. Pengujian dengan EDS yaitu untuk mengetahui komposisi kimia kerak yang terbentuk. Yang paling dominan pada kedua jenis kerak, baik pada flange maupun pipa memiliki unsur dan senyawa yang sama, yang dapat dilihat pada Tabel 7.

Material flange dan pipa penyalur masingmasing memiliki senyawa yang cukup dominan yaitu silika dan besi oksida, yang artinya senyawa tersebut memiliki karakteristik yang sama yaitu keras. Hasil pemeriksaan SEM ditujukan untuk mengetahui jenis dan karakteristik kerak. Pada Gambar 11 dan Gambar 12 hasil pemeriksaan SEM memperlihatkan adanya kerak (scale) yang berwarna putih dan keabu- 
abuan. Ini menunjukkan kerak yang keras seperti silika dan besi oksida. Walaupun kerak tersebut keras namun masih mempunyai sifat porous, sehingga bila ada unsur korosif seperti $\mathrm{Cl}^{-}$dan $\mathrm{S}^{-2}$ akan berpenetrasi ke daerah porous tersebut, dan membentuk korosi sumuran (pitting corrosion). Pada material flange dan pipa penyalur ditemukan unsur $\mathrm{Cl}^{-}$dan $\mathrm{S}^{-2}$ yang terbawa oleh gas alam yang berpenetrasi di daerah scale yang menonjol atau takikan (notch) $[8,9]$.

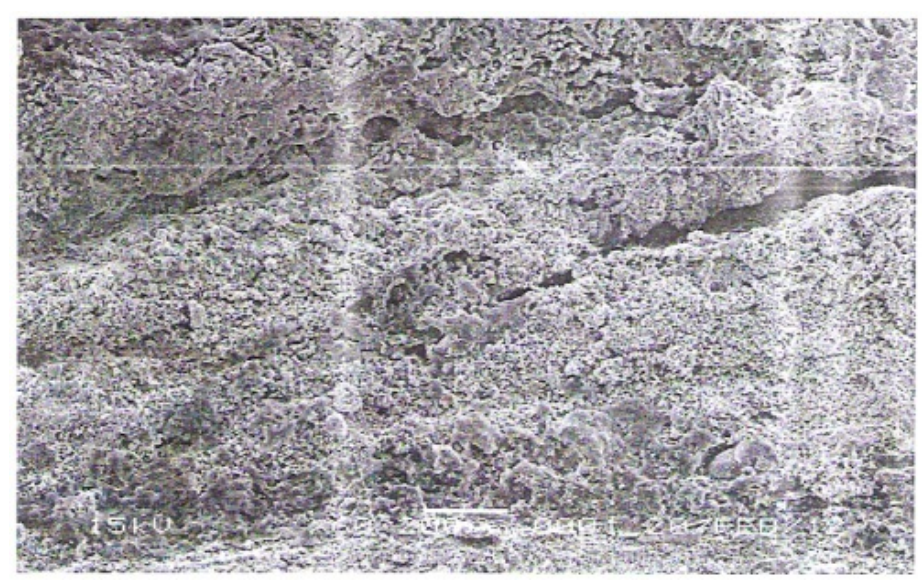

Pembesaran 2000X

Gambar 11. Scale Besi Oksida dan Silika Rapat dan Menyatu

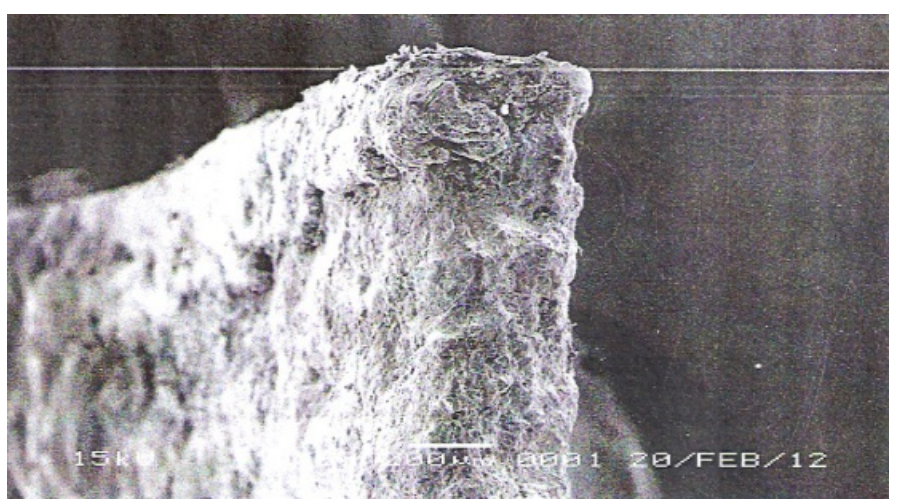

Pembesaran 2000X

Gambar 12. Scale Besi Oksida dan Silika yang Berlapis-Lapis dan Rapat Menyatu

Tabel 7. Dari Hasil EDS Komposisi Kimia Kerak Flange dan Pipa

\begin{tabular}{cclc}
\hline No & Komoditi & Komponen & Jumlah (\%) \\
\hline 1. & Flange & $\mathrm{Si}$ & 1,39 \\
\hline & & $\mathrm{S}$ & 0,01 \\
\hline & & $\mathrm{Cl}$ & 0,03 \\
\hline & & $\mathrm{FeO}$ & 69,39 \\
\hline 2. & $\begin{array}{l}\text { Pipa } \\
\text { Penyalur }\end{array}$ & $\mathrm{Si}$ & 1,99 \\
\hline & & $\mathrm{S}$ & 0,50 \\
\hline & & $\mathrm{Cl}$ & 0,48 \\
\hline & & $\mathrm{FeO}$ & 51,55
\end{tabular}



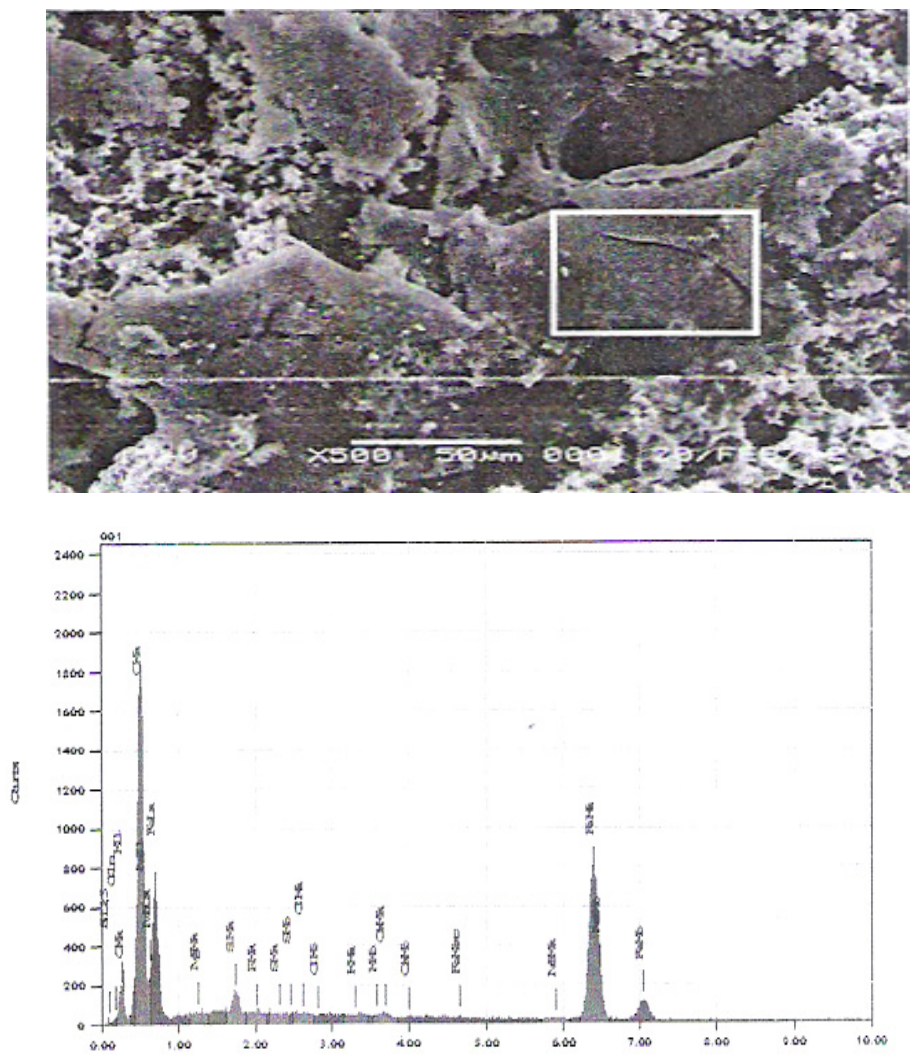

Gambar 13. Hasil Uji SEM dan EDS Produk Korosi

\section{KESIMPULAN DAN SARAN}

\section{Kesimpulan}

Pengamatan secara visualisasi menunjukkan adanya lubang pada sambungan las flange dan reducer, serta pada pipa penyalur. Secara mikroskopis terlihat adanya korosi sumuran (pitting corrosion) yang diawali oleh korosi galvanik atau daerah yang mempunyai kekerasan yang tinggi dan bersifat anodik. Sedangkan, korosi erosi merupakan penyebab pengikisan. Material flange adalah baja tahan karat (SS) dan material reducer dan pipa penyalur adalah baja karbon rendah SA - 234, dan baja karbon rendah SA - 106 B.

Secara makroskopis terlihat adanya sambungan pengelasan logam yang berbeda (dissimilar metal), yang efeknya terhadap kekerasan berbeda, sehingga akan menyebabkan korosi galvanik karena daerah HAZ bersifat anodik yang mempunyai kekerasan lebih tinggi dan lainnya bersifat katodik.

Hasil analisis SEM dan EDS ditemukan silika kompleks yang bersifat sangat keras tapi memiliki sifat porous. Kerak tersebut dihasilkan dari korosi galvanik atau per-mukaan kasar yang mempunyai kekerasan tinggi dan bersifat anodik. Adanya korosi erosi mengikis daerah tersebut. Hasil korosi erosi menjalar dan membentuk korosi sumuran yang didukung adanya anion $\mathrm{Cl}^{-}$dan $\mathrm{S}^{-2}$, sehingga terjadi penipisan dan kebocoran.

\section{Saran}

Penyambungan logam yang berbeda (dissimilar metal) harus dilakukan dengan proses pengelasan buttering dengan spesifikasi yang tepat. Diameter dalam antara flange dan reducer harus diusahkan sama, jangan sampai terjadi aliran penyempitan (bottle neck). Root hasil pengelasan permukaan bagian dalam jangan terlalu menonjol yang merupakan takikan (notch), karena akan terkikis oleh aliran gas, terutama oleh hidrokarbon, $\mathrm{CO}_{2}$, dan hexan $\left(\mathrm{C}^{+6}\right)$ yang menyebabkan aliran turbulensi dan stagnansi. 


\section{UCAPAN TERIMA KASIH}

Penulis mengucapkan termakasih dan penghargaan sebesar-besarnya kepada Ir Adid Andin Hermansyah, Ir. Enuh Rosdeni M. Eng, Ir Eko Budi Prakoso dan Ir Hafid Abdullah, MT atas semua bantuan dan bimbingannya sebagai narasumber sehingga terselesaikannya penelitian ini.

\section{DAFTAR PUSTAKA}

[1] Abdul Wahid, Dikdik Gunantara, 1995, "Analisa Kegagalan Impeller Submersible Pump”, Metal Indonesia, Vol. 17/15, Bandung.

[2] Lilis Yuliasetiawati, 2000, "Pengenalan Korosi”, Metal Industries Development Centre (MIDC) Departemen Perindustrian, Bandung, Hal 2.

[3] ASM METAL Hand Book, 1975, Metal of Microstructure, Vol. 7, 8th Edition, American Society for Metal, Hal. 29-30.
[4] Anonim, 1983, Material Data Books Engineers, Second Edition, International (Student Edition, USA), Hal. 6,7,10.

[5] Anonim, 1996, "Carbon and Alloy Steel”, ASM International, J.R Davis, Ed.

[6] ASM METAL Hand Book, 1995, "Failure Analysis and Prevention", Vol. 11, 9th Edition, American Society for Metal.

[7] Jones Denny, 1992, "Principles and Prevention of Corrosion”, Mac Milan Publishing Company, New York.

[8] Davenport W.G, King. M, Schlesi-nger, Biswas.A.K, 2002, "Extractive Metallurgy of Copper”.

[9] Copper Development Association 2010, The Copper Tube Handbook ,Published 2010 by Copper Development Association Inc, 260, Madison Avenue, New York Ny 100. 